https://www.supportscience.uz/index.php/ojte



\title{
PROBLEMS AND SHORTCOMINGS IN THE CONSTRUCTION OF MODERN HOUSES IN TASHKENT
}

\section{Ikrom Namozov}

Researcher,

Tashkent Institute of Architecture and Civil Engineering

\section{ABOUT ARTICLE}

Key words: problems, construction, modern houses, Tashkent, new materials, construction methods, responsibility, final product, unfortunate consequences, technologies.

Received: 05.12.21

Accepted: 12.12 .21

Published: 17.12 .21
Abstract: This article discusses the problems and shortcomings in the construction of modern houses in Tashkent. As a result, construction companies are cautious in favoring new materials or construction methods. Secondly, there is a high responsibility of builders for the final product, which is explained by the risk of unfortunate consequences, up to a threat to people's lives, if inappropriate technologies are used or mistakes are made at the design stage. This is primarily due to the long service life of buildings and structures, during which unforeseen shortcomings of the technology used may appear.

\section{TOSHKENTDA ZAMONAVIY UYLAR QURILISHIDAGI MUAMMO VA}

\section{KAMCHILIKLAR}

\section{Ikrom Namozov}

Tadqiqotchi,

Toshkent arxitektura-qurilish instituti

\begin{tabular}{ll}
\hline & MAQOLA HAQIDA \\
\hline Kalit so'zlar: muammolar, qurilish, & Annotasiya: Ushbu maqolada Toshkent \\
zamonaviy uylar, Toshkent, yangi materiallar, & shahrida zamonaviy uy-joylar qurishdagi \\
qurilish usullari, mas'uliyat, tayyor mahsulot, & muammo va kamchiliklar haqida so'z boradi. \\
baxtsiz hodisalar, texnologiyalar. & Natijada, qurilish kompaniyalari ehtiyotkorlik \\
& bilan yangi materiallar yoki qurilish usullarini \\
& afzal ko'rishadi. Ikkinchidan, quruvchilarning \\
& yakuniy mahsulot uchun yuqori mas'uliyati \\
& bor, bu nomaqbul oqibatlar xavfi bilan \\
& izohlanadi, agar noto'g'ri texnologiyalar \\
& qo'llanilsa yoki loyihalash bosqichida \\
\hline
\end{tabular}


xatolarga yo'l qo'yilsa, odamlar hayotiga tahdid soladi. $\mathrm{Bu}$, birinchi navbatda, binolar va inshootlarning uzoq xizmat qilish muddati bilan bog'liq bo'lib, uning davomida foydalanilgan texnologiyaning kutilmagan kamchiliklari paydo bo'lishi mumkin.

\section{ПРОБЛЕМЫ И НЕДОСТАТКИ СТРОИТЕЛЬСТВА СОВРЕМЕННЫХ ДОМОВ В ТАШКЕНТЕ}

Икром Номозов

Исследователь,

Ташкентский архитектурно-строительный институт

\section{O СТ A TЬE}

\begin{tabular}{lrr}
\hline \multicolumn{1}{c}{ Ключевые } & \multicolumn{1}{c}{ слова: } & проблемы, \\
строительство, & современные \\
Ташкент, новые & материалы, методы \\
строительства, ответственность, конечный \\
продукт, неблагоприятные последствия, \\
технологии.
\end{tabular}

Аннотация: В данной статье рассматриваются проблемы и недостатки строительства современных домов в Ташкенте. В результате строительные компании с осторожностью отдают предпочтение новым материалам или методам строительства. Во-вторых, высокая ответственность строителей за конечный продукт, что объясняется риском неблагоприятных последствий, вплоть до угрозы жизни людей, при использовании несоответствующих технологий или допущении ошибок на этапе проектирования. В первую очередь это связано с длительным сроком службы зданий и сооружений, в течение которого могут проявиться непредвиденные недостатки применяемой техники.

\section{INTRODUCTION}

Construction is a separate independent area of the country's economy, which is intended for the commissioning of new, as well as the expansion, reconstruction and technical reequipment of existing industrial and non-industrial facilities. The defining role of the industry is to create conditions for the dynamic development of the country's economy. The housing construction industry deserves special attention as the basis for creating comfortable and safe conditions for human life.

In Tashkent and other major cities, measures are being taken to implement new construction in the suburbs.

In recent years, Tashkent has become a construction site, and along with the implementation of comprehensive measures to accelerate construction, effective mechanisms of 
public administration in the field are being introduced. "However, the analysis showed that there are systemic shortcomings and problems in the implementation of construction work, control and transparency," the draft decree reads.

\section{MAIN PART}

In particular:

- $\quad$ first, permitting procedures in the field of urban planning are imperfect, resulting in poor quality and illegal construction;

- $\quad$ secondly, the lack of a mechanism for copyright control by project organizations at the construction site creates problems in the quality of construction, as well as energy saving and efficiency in buildings and structures;

- thirdly, the quality of project documents is declining due to improper development of pre-design documents for design, including technical specifications, terms of reference for design, incomplete copyright control;

- fourth, the mechanism of payment for customer services is not perfect, there are no workloads, material responsibilities, requirements for employees of construction companies;

- $\quad$ fifth, the lack of a system of control over the construction work and the lack of a systematic control over the facilities, as well as the lack of a legal mechanism for organizing construction and introducing production projects into the construction process, impede the clear definition of responsibilities;

- $\quad$ sixth, as a result of unwarranted interference in the construction process by the heads of local authorities and public administration bodies, setting important dates for the early commissioning or commissioning of facilities leads to violations of construction technology and reduced safety of buildings and structures and unreasonable costs;

- $\quad$ seventh, the involvement of inspection bodies by the regulatory authorities as specialists in the systematic inspections, which leads to the inadequate performance of their duties by specialists in the field, the inadequacy of state control;

- $\quad$ eighth, the fact that some construction projects have not been put into operation in accordance with the established procedure, has led to legitimate objections from users of the facilities as a result of the state registration (transfer of ownership) of the facilities.

In order to improve the quality of construction and installation work, eliminate corruption and bureaucratic barriers in the construction industry, introduce effective management mechanisms, strengthen the role and responsibility of the customer, designer, contractor, 
subcontractors in construction and the role of regulatory authorities in the construction industry The right to accredit entities for the control of the construction industry.

In the modern world, market relations have reached a stage at which competition is much more intense. In a state of limited capital resources and a significant degree of competition, the success of domestic enterprises is largely determined by innovation and investment activities. The main reasons for economic growth were previously investments, now the advantages in the market are achieved through the use of innovations. At present, scientific and technological progress, globalization and internationalization of the market are accelerating more and more intensively. In such conditions, it is difficult to maintain competitive advantages for a long time. Construction has features that distinguish this sector of the national economy, they are reflected in the innovation and investment processes of enterprises engaged in this area. The relevance of this article is determined by the conditions of innovative and investment activities of construction enterprises in modern realities, which is a key success factor and contributes to increasing competitiveness in the market.

On the one hand, the construction industry is conservative in relation to the introduction and wide dissemination of innovative technologies. On the other hand, among the innovatively active industries of the leading economic powers, construction is far from being in the first place, but, unfortunately, one of the last. At the same time, the development and implementation of innovations in the field of construction is one of the currently actively developing areas of scientific and technical activity. However, despite the development and use of new technologies, the construction industry is slow and reluctant to respond to innovations in Tashkent. This is primarily due to the long service life of buildings and structures, during which unforeseen shortcomings of the technology used may appear.

As a result, construction companies are cautious in favoring new materials or construction methods. Secondly, there is a high responsibility of builders for the final product, which is explained by the risk of unfortunate consequences, up to a threat to people's lives, if inappropriate technologies are used or mistakes are made at the design stage. When studying innovations in construction, the main attention should be paid to the distinctive industry features of innovations, their target orientation. In relation to the construction industry, it is possible to use the following types of innovations:

- introduction of new solutions in matters of planning and architectural appearance of the facility under construction;

- the use of modern construction machines and equipment, allowing to reduce the construction time and the proportion of costs for their operation; 
-introduction of effective innovative construction technologies (construction of experimental houses);

- improvement of the technology for the production of heat-insulating materials with low cost and at the same time high quality;

- the use of new and high-quality building and finishing materials;

- application of new organizational forms of work performance.

All of these types of innovation exist in close relationship and dictate certain requirements for the innovative activity of enterprises. Technical and technological innovations leave their mark on the content of production construction processes, and also form the conditions for managerial innovations.

In Tashkent, at the present stage of development of the industry, there is a tendency to reduce the share of budget subsidies in the structure sources of innovative financing, while the share of own funds of enterprises is increasing. The widespread introduction of technological innovations in construction is limited by the following factors:

- high commissioning costs of facilities;

- distrust of innovation on the part of buyers;

- lack of financial resources allocated for innovative research;

- the predominance of small firms in the market that do not have sufficient resources to introduce innovations into their activities;

- the cyclical nature of construction and the peculiarities of climatic conditions;

- low degree of integration in the construction industry, provoking a steady dependence on subcontractors;

- lack of a unified system for approbation and certification of new products;

- lack of unlimited access to information about new products, lack of established links, exchange of experience between research centers and construction companies;

- weak support of innovation activities from the state, etc.

The most pronounced reflection of the influence of the above factors is found in domestic housing construction, where innovations are introduced with a significant time lag in relation to trade or industry. In practice, it often happens that innovations, even successfully tested, subsequently do not find mass distribution in construction.

Thus, when introducing innovative technologies in construction, it is necessary to take into account the features that characterize this area as the most conservative, to investigate the factors hindering the introduction of innovations, as well as to maintain and develop the innovative potential of the enterprise. 
At present, investing in the introduction of innovative technologies will allow the company to gain a significant competitive advantage. Most of the really large players in the construction market have become leaders thanks to the active use of new technological solutions.

On October 9, President of the Republic of Uzbekistan Shavkat Mirziyoyev got acquainted with the creative work and major projects being implemented in Tashkent. The President inspected the conditions in the apartments. The spacious, airy apartments have all the amenities. The location of the hotel, kitchen, adult and children's bedrooms, modern design attracts attention. Another advantage of the residential complex is that the apartments are sold ready to live. The exterior of the houses is covered with basalt heating, and each apartment has its own heating system. The business center is scheduled to be fully operational by the end of 2021. "We need to increase the number of houses, reduce energy costs by saving energy. To do this, it is necessary to increase the number of enterprises producing construction materials and basalt fiber and supply them to each region, - said Shavkat Mirziyoyev".

Information was provided on the progress and specifics of the creative work. It was noted that local materials are used in the construction, and the houses are fully equipped with domestic appliances and furniture.

\section{CONCLUSION}

In conclusion, the root causes of a number of problems in society, including those related to modern housing, are the economy, the law, and spirituality. Their solution depends on the promised administrative, financial, judicial, tax, property reforms, the abandonment of monopolies, the pace of the fight against corruption, the formation of civil society and freedom of speech. Unless the complications of the former command-and-control system are completely eliminated, any initiative will remain ineffective.

\section{REFERENCES}

1. Inogamov, B. I., \& Khasanov, A. O. (2021). Taking Into Account Socio-Functional Factors in the Design of Housing. Design Engineering, 2587-2589.

2. Мамадалиева, С. В., \& Сагдуллаева, Д. С. (2020). п-ва м-ферроценилбензой кислоталарнинг айрим диалмашинган хосилаларини у урганиш синфлаш. Образование, 18(19), 20.

3. Ozadovich, K. A., \& Ismailovich, I. B. (2021). Issues of Organization of Service Sets onthe Uzbek National Highway A-380. Design Engineering, 2582-2586.

4. Орифжонова, Г. Р. (2021). ВОПРОСЫ СОЗДАНИЯ ЭТНОГРАФИЧЕСКОГО МУЗЕЯ В УЗБЕКИСТАНЕ. In РАЗВИТИЕ СОВРЕМЕННОГО ОБРАЗОВАНИЯ: АКТУАЛЬНЫЕ ВОПРОСЫ ТЕОРИИ И ПРАКТИКИ (рp. 63-65).

https://www.supportscience.uz/index.php/ojte 
5. Ozodovich, X. A., \& Azim ogli, N. A. (2021). Formation of the "Obod Mahalla" System in the Villages of Uzbekistan and Serving the Population. Барқарорлик ва Етакчи Тадқиқотлар онлайн илмий журнали, 1(5), 325-329.

6. Orifjonova, G. R. (2018). ETHNOGRAPHIC COLLECTIONS OF THE STATE MUSEUM OF TEMURIDS'HISTORY: SAMPLES OF ART OF COPPER-EMBOSSING. ISJ Theoretical \& Applied Science, 4(60), 309-312.

7. Adilovna, Q. S., \& Ozodovich, X. A. (2021). REQUIREMENTS FOR THE PREPARATION OF INTERIORS IN SECONDARY SCHOOLS. Emergent: Journal of Educational Discoveries and Lifelong Learning (EJEDL), 2(11), 74-77.

8. Ozodovich, X. A., Iqramovich, A. R., \& Shaxnazarovich, R. L. (2021). LOCATION OF AUXILIARY ROOMS INSIDE THE LIVING ROOMS IN BUKHARA TRADITIONAL RESIDENTIAL AREAS. Emergent: Journal of Educational Discoveries and Lifelong Learning (EJEDL), 2(11), 61-65.

9. Khasanov, A. (2020). Organizing Eco Tourism Along with Uzbek National Automagistrale Way. Solid State Technology, 63(6), 12674-12678.

10. Orifjonova, G. R. Q. (2019). Ethnographic collections of museums in Uzbekistan: samples of copper-embossing art. Muzeológia a kultúrne dedičstvo, 7(1), 235-240.

11. Khasanov, A. (2016). About several infrastructure constructions of the Great Silk Road. Int'1 J Innov Sci Eng Technol, 3(6), 295-299.

12. Орифжонова, Г. (2021). ХОРИЖ МУЗЕЙЛАРИДАГИ ЎЗБЕКИСТОН ЭТНОГРАФИЯСИГА ОИД ЭКСПОЗИЦИЯЛАР ТАХЛИЛИ. Камолиддин Бехзод номидаги Миллий рассомлик ва дизайн институти АХБОРОТНОМАСИ илмий-амалий журнали, 5(02), 140-147.

13. Ароев, Д. Д. (2020). ОБ ОПТИМИЗАЦИИ ПАРАМЕТРОВ ФУНКЦИИ УПРАВЛЕНИЯ ОБЪЕКТАМИ ОПИСЫВАЕМЫМ СИСТЕМОЙ ДИФФЕРЕНЦИАЛЬНО-РАЗНОСТНЫХ УРАВНЕНИЙ. In Научные исследования молодых ученых (рp. 10-12).

14. Орифжонова, Г. Р. (2019). РОЛЬ ЭТНОГРАФИЧЕСКИХ МУЗЕЕВ В ДЕМОНСТРАЦИИ НАЦИОНАЛЬНО-ЭТНИЧЕСКОЙ КУЛЬТУРЫ. In NATIONAL CULTURES IN SOCIAL SPACE AND TIME (pp. 5-7).

15. Ароев, Д. Д. (2016). ИСПОЛЬЗОВАНИЕ ПОНЯТИЙ" АРИФМЕТИЧЕСКИЕ ДЕЙСТВИЯ НАД МНОГОЗНАЧНЫМИ ЧИСЛАМИ" В МАТЕМАТИЧЕСКИХ ИГРАХ. Актуальные научные исследования в современном мире, (12-4), 16-18.

16. Odilov, B. A., \& Karimov, N. R. (2020). Analysis of Targeted Research in 20-30 Years of the XX Century. PalArch's Journal of Archaeology of Egypt/Egyptology, 17(6), 8887-8893. 
17. Aroev, D. (2021, November). ABOUT THE ROOTS OF A POLYNOMIAL WITH A WHOLE COEFFICIENT. In International Scientific and Current Research Conferences (pp. 14-16).

18. Karimov, N. R. (2020). A True Successor of Great Central Asian Scholars. Journal «Bulletin Social-Economic and Humanitarian Research,(7), 62-69.

19. Aroev, D. D. (2019). PYTHAGORAS AND HIS CONTRIBUTION TO MATHEMATICS. Экономика и социум, (3), 7-10.

20. Omonov, Q., \& Karimov, N. (2020). Importance Of Ancestoral Heritage. The American Journal of Social Science and Education Innovations, 2(09), 196-202.

21. Davronovich, A. D. (2019). The relationship of enzyme activity with the productivity of karakul sheep. Asian Journal of Multidimensional Research (AJMR), 8(3), 59-63.

22. Ароев, Д. Д. (2019). О ПРОВЕРКЕ НА УСТОЙЧИВОСТЬ ДВИЖЕНИЯ ПРОМЫШЛЕННЫХ РОБОТОВ КОТОРЫЕ ОТНОСЯТСЯ К КЛАССУ КООРДИНАТНОГО ЗАПАЗДЫВАНИЯ. In Современный этап мирового научного развития (рp. 3-7).

23. Doniyorov, A. K., \& Karimov, N. R. (2020). An incomparable book of a great scholar. Bulletin Social-Economic and Humanitarian Research, (6), 63-71.

24. Esonov, M. M., \& Aroev, D. D. (2021). ON THE BASICS OF EDUCATION OF MATHEMATICAL THINKING IN THE MODERN COURSE OF GEOMETRY IN A COMPREHENSIVE SCHOOL. European Journal of Research and Reflection in Educational Sciences, 9(3).

25. Ziyamuhamedov, J. T. (2021). Reflection of real life through the bizarre and supernatural in the classic prose of the far east. ACADEMICIA: AN INTERNATIONAL MULTIDISCIPLINARY RESEARCH JOURNAL, 11(1), 1268-1273.

26. Ароев, Д. Д., \& Бабаева, Г. М. (2021). ABOUT THE IMPORTANCE OF INTERESTING EXERCISES IN MATHEMATICS LESSONS. Экономика и соџиум, (2-1), 488-491.

27. Зиямухамедов, Д. Т. (2021). КОНЦЕПЦИЯ ОБЩЕСТВА И ЧЕЛОВЕКА В НОВЕЛЛАХ ПУ СУНЛИНА. Социосфера, (3), 23-31.

28. Davronovich, A. D., \& Ugli, S. A. A. (2021). About A Certain Class Of Non-Associative Algebra. International Journal of Progressive Sciences and Technologies, 25(2), 234-236.

29. Nosirov, C. P. M. S. S., Aroev, D. D., \& Sobirov, A. A. (2021, April). SOME PROPERTIES OF THE DISTANCE BETWEEN TWO POINTS. In E-Conference Globe (pp. 27-28).

30. Зиямухамедов, Д. Т. (2021). Вопросы передачи национального характера в переводах с китайского языка. тельность всем коллегам, принявшим участие в рецен-зировании статей сборника: МЮ Авдониной, СР Агабабян, ВМ Бухарову, ГМ Василь, 86. 
31. Nosirovich, N. S., \& Davronovich, A. D. On Non-Associative Algebra And Its Properties. 